\title{
SERF1A Gene
}

National Cancer Institute

\section{Source}

National Cancer Institute. SERF1A Gene. NCI Thesaurus. Code C158537.

This gene may play a role in the development of the spine. 